\title{
Hydro-Geochemical Characteristics and Quality Evaluations of the Groundwater of an Irrigated Plain Region of Northwestern China
}

Hongying Yuan ( $\nabla$ y15754880179@163.com )

Inner Mongolia Agriculture University: Inner Mongolia Agricultural University https://orcid.org/00000002-5849-0546

\section{Shuqing Yang}

Inner Mongolia Agriculture University: Inner Mongolia Agricultural University

\section{Bo Wang}

Inner Mongolia Agriculture University: Inner Mongolia Agricultural University

\section{Tiankai Han}

water conservancy institution of bayannaoer city

\section{Xuehua Ding}

Inner Mongolia Agriculture University: Inner Mongolia Agricultural University

\section{Research Article}

Keywords: Groundwater resources, hydro-chemical characteristics, control mechanisms, water quality assessments, hydro-geochemistry.

Posted Date: June 25th, 2021

DOI: https://doi.org/10.21203/rs.3.rs-438581/v2

License: (9) This work is licensed under a Creative Commons Attribution 4.0 International License. Read Full License 


\section{Hydro-Geochemical Characteristics and Quality Evaluations of the Groundwater of an Irrigated Plain Region of Northwestern China}

${ }^{a}$ College of Water Conservancy and Civil Engineering, Inner Mongolia Agricultural University, Hohhot 010018, China

bayannaoer City Water Conservancy Research Institute, Bayannaoer City, 015000, China

\section{ABSTRACT}

Groundwater is an important resource of water in arid and semi-arid agricultural regions. In order to study the hydro-geological characteristics and water quality of groundwater in different hydro-geological conditions of plain irrigation areas, 85 groundwater samples were collected for analysis of main chemical ions and evaluation of suitability of irrigation water in Wulate Irrigation Area (WLTIA) and Shenwu Irrigation Area (SWIA). The groundwater was found to be weakly alkaline, Fresh water (47.62\%) was dominant in the SWIA and brackish water $(65.12 \%)$ was dominant in the WLTIA. The hydro-chemical types in the two irrigation areas were observed to be mainly $\mathrm{Cl}-\mathrm{Na}$ and $\mathrm{Cl} \cdot \mathrm{SO}-\mathrm{Ca} \cdot \mathrm{Mg}$, and the ion content was in the order of $\mathrm{Cl}^{-}>\mathrm{SO}_{4}^{2-}>\mathrm{HCO}_{3}{ }^{-}, \mathrm{Na}^{+}>\mathrm{Mg}^{2+}>\mathrm{Ca}^{2+}$. The ion content in the WLTIA was found to be higher than that in the SWIA. This was determined to be mainly due to good soil permeability and groundwater mobility in SWIA but the difficulties encountered in the groundwater exchange process in the WLTIA, as well as the influencing effects of

Corresponding author. E-mail address: nmndysq@126.com. 
the water supply from Wuliangsuhai Lake. The groundwater resources in the two irrigation areas were jointly controlled by evaporation crystallization and rock weathering processes. The dissolution of evaporated salt rock, silicate rock, gypsum, dolomite, and calcite was also a driving factor. This study observed that the chemical compositions of the groundwater in the study area were also affected by ion exchanges and human activities. The evaluation results show that the majority of the groundwater resources in the two irrigation areas could not be directly used for irrigation since salt and alkali damages could easily occur. It was found that the potential for salt damage was relatively serious. This study's comparison results indicated that the quality of groundwater of the SWIA was relatively higher than that of the WLTIA.

Keywords: Groundwater resources; hydro-chemical characteristics; control mechanisms; water quality assessments; hydro-geochemistry.

\section{Introduction}

Groundwater is an important component of water resources, which is vital for human survival and development ( $\mathrm{Li}$ et al.,2018a; Liang et al.,2016). In particular, groundwater plays a decisive role in agricultural production in arid and semi-arid regions where precipitation and surface water resources are scarce (Li et al.,2016b; $\mathrm{Xu}$ et al.,2019). Hydro-chemical research is an important part of hydro-geochemical research (Hao et al.,2020) and a direct factor in the measurements of the quality of groundwater environments ( $\mathrm{Li}$ et al.,2021). The chemical characteristics of groundwater reflect the compositions, types, sources, and control mechanisms of the 
main ion components in groundwater (Saxena et al.,2001; Taheri et al.,2017). Therefore, any changes in groundwater chemical ion concentrations will impact its applicability in industrial and agricultural processes. The formation and evolution of groundwater are not only closely related to natural activities (such as water-rock interactions, ion exchanges, evaporation, and geological factors) (Lin et al.,2012), but have also experienced interference by various human activities (zhang et al.,2018). Therefore, explorations of the hydro-geochemical characteristics and the quality levels of groundwater environments will help reveal the interaction mechanisms of groundwater environments (Chen et al.,2019b)0, groundwater circulation pathways, and succession mechanisms (Wen et al.,2020), as well as providing new insights for groundwater environmental protection and the scientific utilization of groundwater. Such endeavors are of major significance in agricultural irrigation water quality evaluations (Jang et al.,2016; Iqbal et al.,2017).

In recent years, hydro-chemical research has been a hot topic in the fields of hydrology and Earth sciences (Boukhemacha et al.,2018). Chinese and international researchers have carried out a large number of studies regarding groundwater hydro-chemical characteristics in industrial and mining areas (Khalid et al.,2019;Li et al.,2018b;Li et al.,2013); agricultural areas (Chen et al.,2019b;Kumar et al.,2007); basins (Duan et al.,2016;Anantha et al.,2014); basins(Ravikumar et al.,2011;Kawo et al.,2018); and mountainous areas (Li et al.,2016c;Tang et al.,2019). Scientists have conducted in-depth discussions involving the various hydro-geochemical characteristics and formation mechanisms according to the concentration levels of the 
main hydro-chemical elements. It has been determined that there are certain differences in the main control mechanisms of groundwater in different regions. Groundwater is affected by a multitude of factors, such as evaporation and concentration levels; rock dissolution; ion exchanges; water-rock interactions; seawater intrusion; human factors, and so on. However, groundwater is rarely affected by atmospheric precipitation. With increased social development and the intensification of human activities, the chemical characteristics of groundwater have been affected by the interactions of natural processes and human activities (Chen et al.,2017;Hosseinifard et al.,2015). In addition, cross impacts of multiple factors have resulted in groundwater management processes becoming increasing more complex(Li et al.,2017). However, since agricultural water requirements tend to be higher than industrial and domestic water requirements ( $\mathrm{Li}$ et al.,2018a), excessive solute in irrigation water has negatively affected soil quality, crop yields, germination rates, and grain quality, and restricted the development of agricultural related economies in some areas (Jang et al.,2009). In particular, in soil salinization areas, irrigation watering practices need to be more cautious, since improper use of water will not only cause reductions in food production, but also cause other harmful results, such as soil hardening (Chen et al.,2018).

Water quality indexes can directly reflect the water quality levels and provide references for decision makers. At the present time, the common irrigation water quality evaluation indexes include SAR, PI, Na \%, RSC, MH, KR, SH, PS, Ka, and so on (Khalid et al.,2019;Kawo et al.,2018;Tahmasebi et al.,2018). These indexes can 
objectively evaluate the water quality levels and reflect any potential harmful effects. The United States Department of Agriculture (USDA) proposed that sodium absorption ratios (SAR) can be used as effective evaluation indexes for the majority of irrigation water, and this has now been widely recognized. In addition, some researchers have also proposed other methods for determining whether or not irrigation water is suitable using salinity and sodium hazards as the evaluation criteria (Nishanthiny et al.,2010). However, it is worth noting that the conclusions of a single evaluation method may be one-sided. Therefore, eight evaluation indexes were comprehensively used in this study to evaluate the quality of the irrigation water in the study area, including SAR, SSP, RSBC, RSC, MH, KR, PS, and PI, in order to ensure that the results were reliable.

The Hetao Irrigation District of Bayannaoer City is located in the western part of the Inner Mongolia Autonomous Region of China. It is one of the three major irrigation districts in China. It is essentially an impact plain formed by the diversion of the Yellow River, and characterized by flat terrain and abundant cultivated land resources. Although the district is an important food production base in China, drought and low rain conditions have serious impacts on the irrigation area. The limited surface water resources, along with the use of the Yellow River water for irrigation for many years and poor drainage conditions, the groundwater depths in the study area are shallow. As a result, the chemical compositions of the groundwater are affected and problems related to soil salinization have persisted for a long time (Liu et al.,2016). These conditions have seriously affected the local agricultural production processes, as well 
as the environmental health and economic development levels of the region (Ren et al.,2019). In previous studies, a great deal of research data have been accumulated regarding the Hetao Irrigation District. The main focuses of the previous studies have been the water and salt migration processes, irrigation systems, and saline-alkali land improvements(Wang et al.,2019; Shi et al.,2020;Ma et al.,2014;Chang et al.,2020). However, there have been few systematic studies completed regarding the chemical characteristics of groundwater. The current understanding of hydro-geochemical processes and the evolution laws of groundwater chemical ions is relatively weak, and the suitability potential of shallow groundwater for irrigation has not been reported. Furthermore, the intrinsic links between high groundwater solute content, shallow buried depths, and soil salinization cannot be ignored (Zeng et al.,2021). Based on the aforementioned issues, this study selected the Shenwu Irrigation Area located in the upstream diversion control area of the Hetao Irrigation District, and the Wulate Irrigation Area located in the downstream drainage control area as the study area as the study objects. The aforementioned two irrigation areas were considered to be typical hydrogeological units in the Hetao Irrigation District with different groundwater aquifer structures. A total of 85 groups of groundwater samples were collected systematically in the irrigation areas. This study adopted a statistical analysis method; Piper Diagram; Gibbs Model; ion correlation method; Wilcox Diagram; USSL Diagram; Doneen Diagram, and other analytical methods to comprehensively discuss the hydro-geochemical characteristics and main control mechanisms of the main drainage control areas in the Hetao Irrigation District. The 
suitability of the irrigation water was carefully evaluated. The results obtained in this study will be helpful to gain a better understanding of the hydro-geochemical evolution of the study area, and provide an important basis for solving the problems related to soil salinization. It can also provide scientific guidance for the efficient use of groundwater and groundwater environmental protection procedures, and promote the further development of agricultural production industries.

\section{Study area}

\section{Location and climate characteristics}

The Hetao Irrigation District is located in the western section of Inner Mongolia. It is the largest irrigation area in Asia with only one diversion port. The total control area is 17.85 million mu. The climate has the characteristics of an arid and semi-arid continental climate, with an annual average precipitation of approximately $160 \mathrm{~mm}$, and an evaporation rate up to $2,240 \mathrm{~mm}$. The average groundwater depth and salinity of in the irrigation area are $1.83 \mathrm{~m}$ and $3.38 \mathrm{~g} \cdot \mathrm{L}^{-1}$, respectively. Due to the effects of irrigation processes, the groundwater depths during autumn irrigation period are the shallowest, at only $1.56 \mathrm{~m}$, as noted in the statistical data of the Hetao Irrigation District Irrigation Administration (1998 to 2019).

The Shen Wu Irrigation Area is located in the upstream of the Hetao Irrigation District, and is an important water diversion control area of the Hetao Irrigation District. The longitude range is between $106^{\circ} 52^{\prime}$ and $107^{\circ} 04^{\prime}$, and the latitude range is $40^{\circ} 28^{\prime}$ to $40^{\circ} 08^{\prime}$. Its total area is 2.87 million mu. The main water diversion channels in the study area include the Dongfeng main channel and the first main channel, and the first 
and second main drains are its main drainage channels.

The Wulate Irrigation Area is located in the downstream of the Hetao Irrigation District, and is the main drainage control area of the Hetao Irrigation District. The longitude range is from $108^{\circ} 06^{\prime} 12^{\prime \prime}$ to $109^{\circ} 39^{\prime}$, and the latitude range is $40^{\circ} 27^{\prime}$ to $41^{\circ} 10^{\prime}$, with a total area of 30.7 million mu. The main irrigation drains in the area include the Changta diversion channel, Long-ji main channel, Tabu main channel, and the Sanhu River main channel. The main drainage channels include the eighth drainage channel, ninth drainage channel, and the tenth drainage channel.

\section{Hydrogeological settings}

The aquifer in the Hetao Irrigation District is mainly composed of fine-grained alluvial lacustrine deposits formed during the Late Jurassic Period. There are also Holocene-upper Pleistocene lacustrine deposits and alluvial-flood deposits in the area, and lacustrine deposits in the upper part of the middle Pleistocene. The surface layers of the soil are composed of cohesive soil layers containing sandy loam, loam, and clay with thicknesses ranging between 4 and $15 \mathrm{~m}$. The bottom layers are composed of thick layers of fine sand and thin clay layers with thicknesses of approximately $50 \mathrm{~m}$. The sand layers contain gravel layers, which are distributed in the depth ranges of 10 to $15 \mathrm{~m}$ and 30 to $40 \mathrm{~m}$. The upper part of the Middle Pleistocene series is lacustrine with a stable distribution, which is mainly composed of clay and portions of sandy loam.

The Shenwu Irrigation Area is mainly dominated by forest and grassland areas. The aquifer is dominated by sandy soil, with good permeability and smooth groundwater 
flow. The Wulate Irrigation Area is mainly cultivated land, and the aquifer is mainly clay and fine sandy soil. The groundwater flow is slow, or even not flowing, and the groundwater is vulnerable to the recharge of Wuliangsuhai. Both irrigation areas have independent drainage structures. The main discharge mode of groundwater is evaporation, and the recharge mode is agricultural irrigation. There are no natural surface rivers in the two irrigation areas. The artificial surface rivers are seasonal rivers composed of ditches for agricultural irrigation. The groundwater resources are deeply affected by the irrigation practices in the region, and display seasonal fluctuations during the year.

\section{Materials and methods}

\section{Sample collection and analysis processes}

In this study, a total of 85 groundwater samples were collected in September of 2018, including 42 groups in the SWIA and 43 groups in the WLTIA. The sampling well depths were less than $30 \mathrm{~m}$, and the sampling point positions were accurately located using a handheld GPS. The sampling point positions are detailed in Fig. 1. The sample collection and processing procedures used in this study followed the groundwater environmental monitoring technical specifications (2004). The EC values of groundwater samples were measured in-situ using a portable multi-parameter analyzer (DZB-712). The groundwater samples used for the determination of hydro-chemical components were packed in a dry $500 \mathrm{~mL}$ polyethylene bottles. The sampling bottles were repeatedly rinsed with deionized water for drying and back-up use prior to collecting the samples. The groundwater samples were rinsed three times before 
sealing the bottles in order to prevent any influencing effects caused by other impurities. The collected groundwater samples were sent to Bayannaoer Water Resources Research Institute for content determinations within 24 hours, strictly following the standard determination method proposed by the Ministry of Health of the People's Republic of China (GB/t5750-2006)(2006). The pH levels were determined using a glass electrode method. The $\mathrm{K}^{+}$and $\mathrm{Na}^{+}$content levels were determined using flame atomic absorption spectrophotometry, and the $\mathrm{Cl}^{-}, \mathrm{Ca}^{2+}, \mathrm{SO}_{4}{ }^{2-}$, $\mathrm{Mg}^{2+}, \mathrm{HCO}_{3}{ }^{-}$content levels of the samples were obtained using a traditional titration method.

The reliability of groundwater samples was analyzed by calculating the charge balance errors (CBE \%). The calculation method of CBE \% (Li et al., 2018b)0 was as follows:

$$
C B E \%=\frac{\sum \text { cation }-\sum \text { anion }}{\sum \text { cation }+\sum \text { anion }}
$$

The concentration units of anion and cation were meq/L, and the CBE\% results were within $\pm 5 \%$, which indicated that the data were reliable. Therefore, the determination results of the groundwater samples in this study had met the necessary requirements.

\section{Groundwater quality assessments}

In Hetao Irrigation District, the groundwater resources are widely used to irrigate farmland areas and personal gardens, with some directly used for drinking. Its quality directly affects the environmental conditions of the soil and crop growth rates, often hindering agricultural development. Therefore, evaluation results of the groundwater quality can intuitively reflect the chemical compositions of the groundwater and its 
impact on the soil environment. The evaluation results can also provide effective references for local residents and managers. In this study, eight evaluation indexes were selected to evaluate the suitability of groundwater irrigation in the study area,

223 including the SAR (sodium absorption ratio); SSP (sodium percentage); RSBC 224 (residual sodium bicarbonate levels); RSC (residual sodium carbonate levels); MH 225 (magnesium hazard levels); KR (Kelley Ratios); PS (potential salinity); and PI 226 (permeability index). The calculation method was as follows:

In the formula, the ion concentration unit is meq $\cdot \mathrm{L}^{-1}$.

\section{Results and discussion} groundwater in the two irrigation areas was weakly alkaline overall. The $\mathrm{pH}$ range of groundwater in the SWIA was between 7.21 and 8.32 (mean: 7.72), and the pH range 
of groundwater in the WLTIA was between 7.27 and 8.81 (mean: 7.85). The $\mathrm{pH}$ values in the study area were within the standard range (6.5 to 8.5$)$ stipulated by WHO (WHO 2011) and China's groundwater environment quality (Ministry of Health of the PRC and Standardization Administration of the PRC 2017). Only fresh water (TDS $<1000 \mathrm{~g} \cdot \mathrm{L}^{-1}$ ) is suitable for drinking (Ministry of Health of the PRC and Standardization Administration of the PRC 2017; Ministry of Health of the PRC and Standardization Administration of the PRC 2004), since high TDS can change the taste of water (Christensen,2018). Fresh water (TDS $\left.<1 \mathrm{~g} \cdot \mathrm{L}^{-1}\right)$ accounted for $47.62 \%$ of the water in the SWIA, and brackish water $\left(1<\right.$ TDS $\left.<3 \mathrm{~g} \cdot \mathrm{L}^{-1}\right)$ accounted for $65.12 \%$ of the water in the WLTIA. In addition, salt water $\left(3 \mathrm{~g} \cdot \mathrm{L}^{-1}<\mathrm{TDS}\right)$ accounted for $14.29 \%$ and brackish water accounted for $38.09 \%$ of the water in the SWIA. In the WLTIA, it was determined that brackish water accounted for $18.60 \%$ and fresh water accounted for $16.28 \%$. This study found that the TDS of the WLTIA was larger than that of the SWIA. The main reason was that WLTIA was located in the downstream, and TDS displayed significant enrichment. At the same time, the permeability of the soil aquifer in the WLTIA was lower, resulting in the basic stagnation of groundwater flow. The groundwater resources in that area were affected by such factors as the recharge of the Wuliangsuhai, and the fault zone produced by the Wula mountain uplift, which were consistent with the known facts.

From the coefficient of variation, it could be seen that the order of anions in the Shenwu Irrigation Area was $\mathrm{Cl}^{-}>\mathrm{SO}_{4}{ }^{2-}>\mathrm{HCO}_{3}{ }^{-}$; the order of anions in the WLTIA was $\mathrm{SO}_{4}{ }^{2-}>\mathrm{Cl}^{-}>\mathrm{HCO}_{3}{ }^{-}$; and the order of cations in both irrigation areas were $\mathrm{Na}^{+}>$ 
$\mathrm{Mg}^{2+}>\mathrm{Ca}^{2+}$. These findings indicates that $\mathrm{Cl}^{-}, \mathrm{Na}^{+}, \mathrm{SO}_{4}{ }^{2-}$, and $\mathrm{Na}^{+}$were the main salinization ions in the SWIA and WLTIA respectively, and they were sensitive to environmental changes. However, the variation coefficients of $\mathrm{HCO}_{3}{ }^{-}$and $\mathrm{Ca}^{2+}$ in the two irrigation areas were observed to be small, which indicated that the distributions of $\mathrm{HCO}_{3}{ }^{-}$and $\mathrm{Ca}^{2+}$ were stable in the study area. This may have been mainly affected by certain geological factors. The majority of the $\mathrm{Cl}^{-}, \mathrm{Na}^{+}$, and $\mathrm{HCO}_{3}{ }^{-}$content of the groundwater in the two irrigation areas were determined to exceed the drinking limits proposed by WHO $\left(250 \mathrm{mg} \cdot \mathrm{L}^{-1}, 200 \mathrm{mg} \cdot \mathrm{L}^{-1}\right.$, and $\left.300 \mathrm{mg} \cdot \mathrm{L}^{-1}\right)$, indicating that the groundwater in the area was not suitable for human consumption. In addition, the abnormally high values of chemical ions in the water in some areas showed that sewage irrigation practices had certain impacts on the groundwater in the study area.

The orders of the average concentrations of anions and cations in the SWIA was as follows: $\mathrm{Cl}^{-}>\mathrm{SO}_{4}{ }^{2-}>\mathrm{HCO}_{3}{ }^{-}$and $\mathrm{Na}^{+}>\mathrm{Mg}^{2+}>\mathrm{Ca}^{2+}$, respectively. The concentrations of anions and cations in the WLTIA were found to be higher than those in the SWIA. As shown in Fig. 2, the dominant cations in the both irrigation areas were $\mathrm{Na}^{+}$. It has been suggested that the maximum sodium content in irrigation water should be only $60 \%$ (BIS et al.,1991)). In the current study, $\mathrm{Na}^{+}$accounted for $63.96 \%$ and $63.87 \%$ of the total cations in each irrigation area, respectively. Comprehensive evaluations were required prior to the commencement of irrigation processes. The variation range of the $\mathrm{Cl}^{-}$concentrations in the SWIA was large, ranging from $0.09 \mathrm{~g} \cdot \mathrm{L}^{-1}$ to $6.65 \mathrm{~g} \cdot \mathrm{L}^{-1}$. There were found to be 22 samples which exceeded the $250 \mathrm{mg} \cdot \mathrm{L}^{-1}$ limit set by WHO (2008). Meanwhile, the $\mathrm{HCO}_{3}{ }^{-}$content was relatively concentrated (0.11 to $\left.1.74 \mathrm{~g} \cdot \mathrm{L}^{-1}\right)$ 
and higher than the $\mathrm{Cl}^{-}$content. Only ten samples were observed to be below the limit of $300 \mathrm{mg} \cdot \mathrm{L}^{-1}$. The content levels of $\mathrm{Cl}^{-}$in the Wulate Irrigation Area ranged from 0.07 to $25.88 \mathrm{mg} \cdot \mathrm{L}^{-1}$, and the exceeding rate was $81.40 \%$. The concentration of $\mathrm{HCO}_{3}{ }^{-}$ranged from 0.14 to $1.25 \mathrm{mg} \cdot \mathrm{L}^{-1}$, with only four samples not exceeding the $300 \mathrm{mg} \cdot \mathrm{L}^{-1}$ limit. The chloride content levels were found to be high and unstable, which may have been the related to rock weathering, sedimentary rock dissolution, soil leaching, and domestic sewage (Prasanth et al.,2012)0.

\subsubsection{Types of hydro-chemical groundwater}

The chemical ion compositions and evolution characteristics of the groundwater were determined using a Piper Diagram. The cations of the groundwater in the SWIA and WLTIA were mainly concentrated where the $\mathrm{Na}^{+}$has the advantage. The anions in the SWIA were mainly concentrated in the middle of the model, which indicated that the anions were not dominant. The anions in the WLTIA were relatively dispersed, with some concentrated where $\mathrm{Cl}^{-}$had the advantage, and some concentrated in the non-dominant anion areas. The main hydro-chemical types of the two irrigation areas were $\mathrm{Cl}-\mathrm{Na}$ types and $\mathrm{Cl} \cdot \mathrm{SO}-\mathrm{Ca} \cdot \mathrm{Mg}$ types, which indicated that the groundwater in the study area may be affected by carbonate dissolution in which large amounts of $\mathrm{Ca}^{2+}$ and $\mathrm{Na}^{+}$are released into the groundwater. At the same time, the ion composition of the groundwater in the WLTIA was found to be more dispersed than that in the SWIA. These findings suggested that the groundwater hydro-chemical characteristics in that area varied greatly and were affected by many factors (Liu et al.,2021). Generally speaking, the chemical composition types of groundwater in the two 
irrigation areas were observed to be diverse, and may have been affected by the evaporation concentration levels, ion exchange processes, and other factors.

\subsubsection{Hydro-chemical control mechanisms}

The Gibbs Diagram is widely used in groundwater chemistry research. It is mainly used to macroscopically reflect the natural formation mechanisms of regional groundwater (Li et al.,2016b;Marghade et al.,2012). The Gibbs Diagram is mainly divided into three control mechanisms: evaporation concentration, rock weathering, and atmospheric precipitation (Li et al.,2013; Gibbs et al.,1970; Wu et al.,2015). As shown in Fig. 4, the majority of the groundwater sample locations in the SWIA were in a rock weathering zones, with a small portion located in evaporation and concentration zones. Meanwhile, the majority of the groundwater samples obtained in the WLTIA were affected by evaporation and concentration levels, which indicated that the chemical composition of the groundwater in the area was jointly affected by rock leaching ( $\mathrm{Li}$ et al.,2016c) and evaporation and concentration levels. This was mainly due to the fact that the SWIA was an alluvial plain formed by the Yinshan Mountains. The groundwater flow was good, and was recharged by the fissure water of the Yinshan rock formations. The farmland irrigation areas in the WLTIA accounted for a large proportion. The groundwater flow was poor and the burial depths of the groundwater were shallow. In addition, the lack of rainfall increased the evaporation intensity in the area. Another part of the sampling points were distributed outside the Gibbs Diagram, which indicated that the groundwater in the study area was affected by human factors to some extent (Yuan et al.,2019). Due to the shallow 
groundwater depths in the region, it was easily infiltrated by rainwater and irrigation water, such as the water used in agricultural irrigation, fertilization, and industrial development processes.

In this study, it was determined by the relationships between the $\mathrm{Ca}^{2+} / \mathrm{Na}^{+}$and $\mathrm{HCO}_{3}{ }^{-} / \mathrm{Na}^{+}, \mathrm{Mg}^{2+} / \mathrm{Na}^{+}$in the groundwater that the influencing effects of different rock weathering and leaching conditions on the water solute could be distinguished (Gailla et al.,1999)0. As can be seen in Fig. 5, the majority of the sampling points in the two study areas were distributed between the evaporite and carbonate rock, with some approaching the silicates. These findings indicated that the sources of the groundwater hydro-chemical components in the study area were complex and affected by many factors. This was mainly controlled by the actions of the evaporite and silicate rock. However, the carbonate rock also affected the chemical compositions of the groundwater in the study area to some extent.

\subsubsection{Sources of major ions}

The main sources of $\mathrm{Na}^{+}$can be determined according to the ratio relationships between the $\mathrm{Na}^{+}$and $\mathrm{Cl}^{-}$(Zhang et al.,2020). For example, if the ratio is 1, the sources come from the dissolution of evaporated salt rock. However, if the ratio is greater than 1, the sources can be known to have originated from the weathering of silicate rock (He et al.,2021). Fig. 6(a) illustrates that the majority of the sampling points in the two examined irrigation areas were located near to or on the right side of the 1:1 ratio line. Therefore, the groundwater in the study area was mainly affected by the dissolution of evaporated salt rock and the weathering of silicate rock. Only a few 
351

352

points in the WLTIA were found to be located above the 1:1 line, and those were determined to be affected by the evaporation and concentration levels. The advantage of $\mathrm{Na}^{+}$over $\mathrm{Cl}^{-}$in the Shenwu Irrigation Area may have been due to cation exchanges and silicate dissolution processes ( $\mathrm{Li}$ et al.,2018b; Carol et al.2012; Kumar et al.2006).

It was determined that if the $\mathrm{Ca}^{2+} / \mathrm{SO}_{4}{ }^{2-}$ ratio was approximately 1 , the dissolution of gypsum was the main source of the groundwater in the region (Chen et al.2019b). As shown in Fig. 6(b), the groundwater sampling points in the two irrigation areas were partially concentrated near the 1:1 line. However, the groundwater in the SWIA was located at the upper end of the 1:1 line, which indicated that the evaporation of $\mathrm{Ca}^{2+}$ and $\mathrm{SO}_{4}{ }^{2-}$ in the groundwater of that irrigation area was also an important factor, in addition to the gypsum dissolution (Marghade et al.2012). In addition, some of the sampling points in the WLTIA were located below the 1:1 line, which indicated that carbonate dissolution (such as dolomite and calcite) may also be an important source of $\mathrm{Ca}^{2+}$, along with the gypsum dissolution (Wu et al.2014).

In summary, when $\left(\mathrm{SO}_{4}{ }^{2-}+\mathrm{Cl}^{-}\right) / \mathrm{HCO}_{3}{ }^{-}<1$, the chemical components of water mainly come from the dissolution of carbonate. However, when $\left(\mathrm{SO}_{4}{ }^{2-}+\mathrm{Cl}^{-}\right) / \mathrm{HCO}_{3}{ }^{-}>1$, the chemical components of water mainly come from the dissolution of evaporated salt rock (Wang et al.2009). As can be seen in Fig. 6(c), the groundwater sampling points in the SWIA and WLTIA mainly fell above the 1:1 line. These results indicated that the dissolution of evaporated salt rock was an important source of the hydro-chemical compositions in the two irrigation areas. It was observed that only a few sampling 
points were located at the lower side of the 1:1 line, indicating that those areas were mainly controlled by the dissolution of carbonate rock.

It was found in this study that if $\left(\mathrm{Ca}^{2+}+\mathrm{Mg}^{2+}\right) / \mathrm{HCO}_{3}{ }^{-}=1$, only the carbonate rock had potentially participated in the dissolution processes (Chen et al.2019a). In addition, if groundwater samples were concentrated between 1:1 and 2:1, it was indicated that the dissolution of calcite and dolomite was the main process of the $\mathrm{Ca}^{2+}$ and $\mathrm{Mg}^{2+}$ sources (Li et al.2013; Li et al.2016a). As can be seen in Fig. 6(d), the groundwater samples in the two irrigation areas generally fell on the 1:1 line or between the 1:1 and 1:2 lines. Therefore, it was determined that the dissolution of carbonate rock (dolomite and calcite) was the main process. The groundwater sampling points in the WLTIA fell above the 1:2 line, and the content levels of $\mathrm{Ca}^{2+}$ and $\mathrm{Mg}^{2+}$ were found to be higher than those of $\mathrm{HCO}_{3}^{-}$. Therefore, it was indicated that in addition to the dissolution of carbonate rock, there were other sources of mineral dissolution in the groundwater of the irrigation area, such as the dissolution of gypsum and silicate.

In addition, it was determined that if the $\left(\mathrm{HCO}_{3}{ }^{-}+\mathrm{SO}_{4}{ }^{2-}\right) /\left(\mathrm{Ca}^{2+}+\mathrm{Mg}^{2+}\right)$ was approximately 1 , the dissolution of carbonate and sulfate minerals was the main process affecting the chemical compositions of the groundwater in the region ( $\mathrm{Li}$ et al.2018b; Barzegar et al.2017). As detailed in Fig. 6(e), the majority of the sampling points in the two irrigation areas were located below the ratio line, indicating that the $\mathrm{HCO}_{3}{ }^{-}+\mathrm{SO}_{4}{ }^{2-}$ had obvious advantages for $\mathrm{Ca}^{2+}+\mathrm{Mg}^{2+}$. This may have been due to silicate weathering and ion exchanges. However, a small number of the samples were above the ratio line in the WLTIA, which suggested that reverse cation exchanges 
395

396

397

398

399

400

401

402

403

404

405

406

407

408

409

410

411

played a certain role in controlling the groundwater in the WLTIA (Xu et al.2019). At the same time, if the value of $\left(\mathrm{Ca}^{2+}+\mathrm{Mg}^{2+}-\mathrm{SO}_{4}{ }^{2-}-\mathrm{HCO}_{3}{ }^{-}\right) /\left(\mathrm{Na}^{+}+\mathrm{K}^{+}+\mathrm{Cl}^{-}\right)$was approximately -1 , it was determined that the groundwater in the study area had undergone ion exchange adsorption processes ( $\mathrm{Li}$ et al.2016c; $\mathrm{Li}$ et al.2016a). As shown in Fig. 6(f), the slopes of the two irrigation areas' $\left(\mathrm{Ca}^{2+}+\mathrm{Mg}^{2+}-\mathrm{SO}_{4}{ }^{2-}-\mathrm{HCO}_{3}{ }^{-}\right) /\left(\mathrm{Na}^{+}+\mathrm{K}^{+}+\mathrm{Cl}^{-}\right)$were 0.93 and 1.01 , respectively, which were close to 1 . This indicated that cation exchanges were dominant in both irrigation regions, while a small portion of reverse cation exchanges also existed in the Wualte Irrigation Area.

\subsubsection{Impacts of human activities}

The rapid development of industry and agriculture, along with the intensification of human activities, have greatly affected the content of groundwater components. The Hetao Irrigation District is an alluvial plain formed by the diversion of the Yellow River. It has been an important agricultural region for many years. Since there are no natural rivers in the area, there are less available water resources. The drought and lower rain conditions in the area have required the local farmlands to be irrigated using the Yellow River water for more than 2,000 years. From 2009 to 2018, the average annual water diversion into the SWIA and WLTIA was 505 and 438 million $\mathrm{m}^{3}$, respectively, and the drainage volume was only 0.07 and 0.87 million $\mathrm{m}^{3}$ (Fig. 7).

Flooding irrigation methods using large quantities of water were adopted for agricultural irrigation. As a result, such problems as the silting up of drainage ditches and small hydraulic gradients have made the drainage volumes and groundwater 
depths in this area smaller. The groundwater buried depths are now less than $3 \mathrm{~m}$ in the two irrigation areas, which account for $76.21 \%$ and $80.11 \%$ of the total area, respectively (Fig. 8). Under the aforementioned conditions, agricultural fertilization and industrial emissions easily infiltrate into the groundwater with irrigation water or precipitation, which changes the chemical compositions of the groundwater in these districts.

\subsection{Suitability evaluation results of the irrigation water}

When groundwater is used for irrigation, both salt and alkali hazards must be considered ( $\mathrm{Li}$ et al.2013b). This is particularly true in areas where soil salinization is serious. Under such conditions, irrigation water requires more attention. The SWIA and WLTIA are considered to be typical representatives of different geological conditions in the Hetao Irrigation District. Water quality evaluations are particularly important for guiding farmland irrigation processes in the region (Kumar et al.2007; Tahmasebi et al.2018). In this study, the following eight indexes were included in order to evaluate the irrigation water quality: SAR, SSP, RSBC, RSC, MH, KR, PS, and PI.

\subsubsection{Sodium absorption ratios and sodium percentages (SAR and SSP)}

SSP and SAR are important indicators of sodium hazards. For example, if the values of SSP and SAR are too large, they will harm the permeability and structure of the soil (Tang et al.2019), thereby inhibiting crop water absorption (Barzegar et al.2017). In accordance with the SSP, the water quality can be divided into the following five levels: Excellent (SSP < 20\%); good $(20 \%<$ SSP < 40\%); permissible $(40 \%<$ SSP < 
$60 \%)$, doubtful $(60 \%<$ SSP < 80\%); and unsuitable (SSP > 80\%) (Wilcox et al.1955).

In addition, according to the SAR, the water quality can be divided into the following

four levels: Excellent (SAR < 10); good $(10<\mathrm{SAR}<18)$; doubtful $(18<\mathrm{SAR}<26)$; and unsuitable (SAR > 26) (Ravikumar et al.2011). This study's evaluation results were illustrated using Wilcox Diagrams (Li et al.2016c;Wilcox et al.1955) and USSL Diagrams, respectively.

The results of previous related studies have pointed out that the maximum SSP value of irrigation water cannot exceed 60\% (Prasanth et al.2012). Therefore, groundwater resources in excellent and good water quality areas can be directly used for irrigation. It was determined in this study that the groundwater in the SWIA and WLTIA which could be directly used for irrigation accounted for $42.86 \%$ and $18.60 \%$, respectively. It was found that the groundwater in the SWIA was of better quality than that in the WLTIA to some extent. In addition, $28.57 \%$ and $18.60 \%$ of the water samples were determined to have SSP values exceeding $60 \%$ of the limit value in the two examined irrigation areas, respectively. The high SSP values in the SWIA may have been due to the increases in $\mathrm{Na}^{+}$content caused by cation exchange effects (Khalid et al.2019). If the groundwater resources in those areas, as well as those in the doubtful and unsuitable areas, are used for irrigation, certain harmful effects may result to both the soil and crops (Xu et al.2019). Therefore, carefully consideration should be given when directly using those water sources for irrigation purposes. The USSL Diagram takes EC as the abscissa and SAR as the ordinate. The EC represents salt damage and the SAR represents alkali damage. The variation range of 
the SAR values in the SWIA was between 1.49 and 35.55 (mean: 7.79). The variation range of the SAR values in the WLTIA was between 1.02 and 35.40 (mean: 8.55). As can be seen in Fig. 10, only one sample was located in the C2S1 region in the SWIA and WLTIA, respectively, with medium salt and low sodium content. This was considered to be suitable for irrigation. However, the majority of the groundwater samples in the two irrigation areas were concentrated in the $\mathrm{C} 3 \mathrm{~S} 1$ area. Among those, the SWIA accounted for $59.52 \%$, and WLTIA accounted for only $37.21 \%$. These types of water belongs to the category of high salt and low sodium water, which can only be used for the irrigation of crops with good salt tolerance (Li et al.2016a) or soil with good drainage conditions (Kawo et al.2018;Singh et al.2009). In addition, $19.05 \%$ and $37.21 \%$ of the sampling points in SWIA and WLTIA, respectively, were scattered in $\mathrm{C} 4$ area, which indicated that the potential for salt and alkali damage could not be ignored when groundwater was used for irrigation in those areas. In summary, this study determined using the analysis results of the SSP and SAR that the majority of the groundwater in the two irrigation areas was not suitable for irrigation due to high salinity or alkalinity levels. In addition, the potential for harm caused by salinity was found to be more serious than that of alkalinity.

\subsubsection{Residual sodium carbonate (RSC) and residual sodium bicarbonate}

\section{(RSBC)}

The determination of residual sodium carbonate (RSC) levels is significant for irrigation water suitability evaluations (Khalid et al.2019; Kawo et al.2018). When irrigation water with high RSC values are used, sodium carbonate depositing and 
483

484

485

486

487

488

489

490

491

492

493

494

495

496

497

498

499

500

501

502

503

decreased soil fertility may occur (Li et al.2016c; Joshi et al.2009). The RSC range of the groundwater in the SWIA was observed to be between -26.59 and $7.42 \mathrm{meq} \cdot \mathrm{L}^{-1}$, with an average of $-3.63 \mathrm{meq} \cdot \mathrm{L}^{-1}$. The RSC range of the groundwater in the WWLTIA was between -29.31 and $15.96 \mathrm{meq} \cdot \mathrm{L}^{-1}$, with an average of $-5.37 \mathrm{meq} \cdot \mathrm{L}^{-1}$. According to the RSC values, more than $90 \%$ of the groundwater in the two irrigation areas could be classified as good quality water, which could be directly used for irrigation. Four samples in the two irrigation areas were evaluated as suspicious, with the potential of being harmful to the soil and crops. Therefore, it was concluded that the possibility of damages caused by sodium carbonate deposition in the groundwater of the study area was very small.

A method for the determination of residual sodium bicarbonate RSBC (Gupta et al.1987) levels was proposed by Gupta in 1987, in which the water quality was divided into five alkalinity levels. In the SWIA and WLTIA, eight samples and 13 samples were collected, respectively. The proportions of alkaline water were $80.95 \%$ and $69.77 \%$, respectively, which could potentially increase soil alkalinity when used for irrigation (Table 2).

\subsubsection{Magnesium hazard (MH) levels}

The magnesium hazard $(\mathrm{MH})$ levels reflect the impact of $\mathrm{Mg}^{2+}$ content in irrigation water on soil environments (Tahmasebi et al.2018). If the MH values are less than 50, the water is considered suitable for irrigation. However, if the MH values more than 50, the water is not suitable for irrigation (Abdulhussein et al.2018). This is mainly due to the high content of $\mathrm{Mg}^{2+}$, which will not only lead to soil alkalinity, but may 
505

506

507

508

509

510

511

512

513

514

515

516

517

518

519

520

521

522

523

524

525

526

also affect soil permeability (Xu et al.2019; Khalid et al.2019; Ravikumar et al.2011).

The MH values of the SWIA ranged between $30.20 \%$ and $83.52 \%$, with an average of $58.67 \%$. Among those, the MH values of $26.19 \%$ of the samples were less than $50 \%$, and $73.81 \%$ samples were more than $50 \%$. The mean value of the $\mathrm{MH}$ was $59.77 \%$ $(19.07 \%$ to $89.01 \%)$. It was found that only eight samples were less than $50 \%$ and $81.40 \%$ of the samples were more than $50 \%$.

\subsubsection{Kelley Ratios (KR)}

Kelley et al. (1941) suggested that the ratios of sodium to calcium and magnesium should not exceed 1:1 (Krishnakumar et al.2014). In this study, the Kelly Ratio (KR) values of SWIA were determined to be between 0.37 and 5.67 , with $42.86 \%$ of the samples less than 1 . The KR values of the WLTIA ranged between 0.24 and 8.12 , with $48.84 \%$ of the samples less than 1 . In addition, there were 24 and 21 samples, respectively, greater than 1 in the two irrigation areas, which indicated that those samples were not suitable for irrigation.

\subsubsection{Potential salinity (PS)}

Potential salinity (PS) is another important indicator which is used to determine whether or not groundwater is suitable for irrigation (Tahmasebi et al.2018). Its classification method is shown in Table 3. The variation range of the PS values in the SWIA was between 3.75 and $61.95 \mathrm{meq} \cdot \mathrm{L}^{-1}$, with an average of $13.50 \mathrm{meq} \cdot \mathrm{L}^{-1}$. All of the samples in the area belonged to the "good to injurious" and "injurious to unsatisfactory" categories. The variation range of the PS values in the WLTIA was between 2.75 and $96.65 \mathrm{meq} \cdot \mathrm{L}^{-1}$, with an average of $20.13 \mathrm{meq} \cdot \mathrm{L}^{-1}$. It was found that 
only one sample in irrigation area was in the category of "excellent to good". These findings indicated that the majority of the groundwater in the two irrigation areas was not suitable for irrigation, and that rock mass leaching may be the main source of the $\mathrm{Cl}^{-}$and $\mathrm{SO}_{4}{ }^{2-}$.

\subsubsection{Permeability index (PI)}

Permeability indexes (PI) can be used to evaluate the effects of irrigation water on soil permeability (Singh et al.2009). According to the values of the PI, the irrigation water quality can be divided into three categories: Type I water (PI > 75\%); Type II water $(25 \%<\mathrm{PI}<75 \%)$; and Type III water (PI < 25\%). Type I and Type II are suitable for irrigation. However, Type III is not suitable for irrigation (Doneen et al.1962). As detailed in Fig. 11, the irrigation water quality of the SWIA and WLTIA was mainly distributed in the Type I category, and the permeability coefficient is more than $75 \%$. Therefore, the influencing effects of the groundwater on soil permeability in the study area were very small. Therefore, based on the evaluation results of the PI values, it was preliminarily judged that the groundwater in the study area was suitable for irrigation. However, it should be noted that according to the PI calculation formula, the high permeability indexes of the groundwater in the study area were likely related to the high content of sodium ions and bicarbonate in the examined water samples.

Generally speaking, this study found that the majority of the groundwater resources in the two examined irrigation areas were not suitable for irrigation. Although some evaluation results revealed that the use of groundwater in the region for irrigation would not affect the soil permeability, the evaluation results of a single index could 
not be considered as sufficient to explain the water quality issues. The problems related to salt and alkali damages were still very prominent, and comprehensive evaluations should be conducted prior to irrigation procedures being implemented.

\section{Conclusions}

Groundwater plays an important role in agricultural development. Human activities and environmental factors have great impacts on the groundwater environment. However, unreasonable utilization of groundwater resources will not only reduce soil quality, but also affect crop yields. In this study, a variety of methods were used to explore the chemical compositions and control mechanisms of the groundwater resources in the study area. In addition, a variety of evaluation indexes were selected to comprehensively evaluate the suitability of the groundwater for irrigation. Based on the obtained results, the following conclusions were drawn.

1. The results of this study's statistical analysis showed that fresh water was dominant in the SWIA and brackish water was dominant in the WLTIA, and both areas displayed weak alkaline levels. The order of ion concentration was $\mathrm{Cl}^{-}>\mathrm{SO}_{4}{ }^{2-}>\mathrm{HCO}_{3}{ }^{-}$and $\mathrm{Na}^{+}>\mathrm{Mg}^{2+}>\mathrm{Ca}^{2+}$ in the SWIA and WLTIA, respectively. The ion content in the WLTIA was found to be higher than that in the SWIA, which was mainly due to good soil permeability and groundwater mobility in SWIA but the poor groundwater fluidity in the WLTIA. Also, the long-term retention caused 
571

572

573

574

575

576

by the difficulty of groundwater exchanges and the recharge of the Wuliangsuhai reclaimed water were also important factors. This study's Piper Diagram revealed that the dominant anions and cations in the two examined irrigation areas were $\mathrm{Cl}^{-}$and $\mathrm{Na}^{+}$, and the hydro-chemical types were mainly $\mathrm{Cl}-\mathrm{Na}$ and $\mathrm{Cl} \cdot \mathrm{SO}-\mathrm{Ca} \cdot \mathrm{Mg}$. In addition, the concentration levels of $\mathrm{Cl}^{-}, \mathrm{Na}^{+}$, and $\mathrm{SO}_{4}{ }^{2-}$ in some of the samples obtained in the WLTIA were observed to be very high, which was determined to be mainly due to ion exchanges, human activities, and rock dissolution.

2. According to the Gibbs Diagram, the groundwater in the two irrigation areas was mainly controlled by rock weathering and evaporation crystallization. The results of ion endmember diagram showed that the chemical ion sources of the groundwater in the two irrigation areas were mainly evaporated salt rock, silicate rock, gypsum, and dolomite and calcite dissolution. In addition, the evaporation and concentration levels, ion exchanges, and human activities were also important factors affecting the chemical compositions of the groundwater in the study area. Among those, the reverse cation exchanges in the WLTIA could not be ignored, as these may have been important sources of the excessive $\mathrm{Cl}^{-}$in some of the samples.

3. According to the evaluation results of the SAR (sodium absorption ratio); SSP (sodium percentage); RSBC (residual sodium bicarbonate); RSC (residual sodium carbonate); MH (magnesium hazards); KR (Kelley 
594 determined that the groundwater in the study area was not suitable for 595 irrigation. Although some sample evaluation results showed that soil 596 permeability would not be affected when the groundwater was used for 597 598

ratios); PS (potential salinity); and PI (permeability indexes), it could be permeability would not be affected when the groundwater was used for irrigation, based on the other evaluation results, it was considered likely that the high concentration of $\mathrm{Na}^{+}$and $\mathrm{HCO}_{3}{ }^{-}$in the groundwater and the low content of $\mathrm{Mg}^{2+}$ may have led to a single evaluation result with low reliability. In addition, the potential for groundwater salt damage in the study area was very prominent. Overall, the multi-index evaluation results obtained in this study showed that the groundwater of the SWIA was of better quality than that of the WLTIA.We should be cautious when using groundwater for irrigation in this area.

\section{Ethical Approval}

This paper has not been published in other journals.

\section{Consent to Participate and Consent to Publish}

All authors approve Participating and Publishing in Environmental Science and Pollution Research Journal.

\section{Credit authorship contribution statement}

Hongying Yuan:Formal analysis, Investigation, Writing-original draft, Visualization.Shuqing Yang:Conceptualization, Methodology, Writing - review \& editing, Supervision, Project administration.Bo Wang:Investigation. Tiankai Han:Investigation. Xuehua Ding:Data curation, Writing - review \& editing. 
616 The authors declare that they have no known competing financial interests or personal 617 relationships that could have appeared to influence the work reported in this paper.

\section{Acknowledgements}

619 This research was supported by Major science and technology project of Inner 620 Mongolia (zdzx2018059), Science and technology plan project of Inner Mongolia 621 Autonomous Region (201802084), and Research and demonstration of key 622 technologies for farmland conservation and soil fertility improvement in the northern 623 agro-pastoral zone (201802065).

624 Availability of data and materials

625 All data and samples come from actual collections and measurements.

626 References

627

Abdulhussein, F.M. Hydrochemical Assessment of Groundwater of Dibdibba Aquifer in Al-Zubair Area,Basra, South of Iraq and its Suitability for IrrigationPurposes. Iraqi J. Sci. 2018, 59, 135-143.

Anantha, R.V .; Chandrakanta, G. Major ion chemistry, hydro-geochemical studies and mapping of variability in ground water quality of Sitanadi basin, Southern Karnataka. Octa J. Environ. Res. 2014, 2, 178-196.

Barzegar, R.; Moghaddam, A.A.; Tziritis, E.; Fakhri, M.S.; Soltani, S. Identification of hydrogeochemical processes and pollution sources of groundwater resources in the Marand plain, northwest of Iran.Environ. Earth Sci. 2017, 76, 297.

BIS (1991) Bureau of Indian Standards - Indian standard specification for drinking water IS: 10500.

Bureau of Quality and Technical Supervision of China. National Standard of the People's Republic of China:Quality Standard for Groundwater; GB/T 14848-2017; Bureau of Quality and Technical Supervision of 
China:Beijing, China, 2017. (In Chinese)

Boukhemacha M A, Gogu C R, Serpescu I, Gaitanaru D, Bica I. A hydrogeological conceptual approach to study urban groundwater flow in Bucharest City, Romania[J]. Hydrogeology Journal, 2015, 23(3): 437-450.

Carol, E.S.; Kruse, E.E.; Laurencena, P .C.; Rojo, A.; Deluchi, M.H. Ionic exchange in groundwater hydrochemical evolution. Study case: The drainage basin of El Pescado creek (Buenos Aires province,Argentina).Environ. Earth Sci. 2012, 65, 421-428.

Chang F D,Wang G L,Zhang X L,Zhang H Y,Song J K,Lu C,Feng H C,Ji H J,Li Y Y.Regulation effect of spring irrigation combined with straw interlayer onsaline-alkali soil temperature in Hetao Irrigation District[J].Journal of Plant Nutrition and Fertilizers,2020,26(11):1987-1997.(In Chinese)

Chen C, Gao Z J, Li W, Lu Y,Lv L, Liu Y Q,Deng Q J, Qi X J. Characteristics and possible factors hydrochemistry in the groundwater in Tailai basin [J]. Environmental Chemistry, 2019a, 38(6): 1339-1347.(In Chinese)

Chen, J.; Huang, Q W.; Lin, Y .; Fang, Y .; Qian, H.; Liu, R.; Ma, H. Hydrogeochemical Characteristics and Quality Assessment of Groundwater in an Irrigated Region, Northwest China. Water 2019b, 11(1).

Chen, J.; Qian, H.; Gao, Y .; Li, X. Human Health Risk Assessment of Contaminants in Drinking Water Based on Triangular Fuzzy Numbers Approach in Yinchuan City, Northwest China. Expo. Health 2018, 10, 155-166.

Chen, J.; Wu, H.; Qian, H.; Gao, Y . Assessing nitrate and fluoride contaminants in drinking water and their health risk of rural residents living in a semiarid region of Northwest China. Expo. Health 2017, 9, 183-195.

Christensen, J.N.; Dafflon, B.; Shiel, A.E.; Tokunaga, T.K.; Wan, J.; Faybishenko, B.; Dong, W.; Williams, K.H.;Hobson, C.; Brown, S.T.; et al. Using strontium isotopes to evaluate the spatial variation of groundwater recharge. Sci. T otal Environ. 2018, 637-638, 672-685.

Doneen LD (1962) The influence of crop and soil on percolating waters. In: Schiff L (ed.) Proceedings of the 1961 Biennial conference on Groundwater recharge, pp 156-163. 
Duan, L.; Wang, W.K.; Sun, Y .B.; Zhang, C.C. Iodine in groundwater of the Guanzhong Basin, China: Sources and hydrogeochemical controls on its distribution. Environ. Earth Sci. 2016, 75, 970.

Gailla Jrdet J, Dupré B, Louvat P. 1999.Global silicate weathering andCO2consumption rates deduced from the chemistry of largerivers[J]. Chemical Geology, 159( 14) : 3-30.

Ghalib, H.B. Groundwater chemistry evaluation for drinking and irrigation utilities in east Wasit province, Central Iraq. Appl. Water Sci. 2017, 7, 3447-3467.

Gibbs, R.J. Mechanisms controlling world water chemistry . Science 1970, 170, 1088-1090.

Groundwater environment testing technical specification, HJ/T164-2004[S].(In Chinese)

Gupta SK, Gupta IC (1987) Management of saline soils and water. Oxford and IBM Publ. Co, New Delhi, p 399.

Hao Y R, Wang P, Zhang M Z, Zhang J, Li D, Pang Y. Hydrochemical characteristic and its driving force of groundwater in the covered karst in Pearl River Basin[J]. Ecology and Environmental Sciences, 2020, 29(2): 337-344.(In Chinese)

He M X,Zhang B,Xia W X, Cui X, Wang Z L.Hydrochemical Characteristics and Analysis of Qilihai Wetland, Tianjin[J].Environmental Science, ,2021,42(02):776-785.(In Chinese)

Hosseinifard, S.J.; Aminiyan, M.M. Hydrochemical Characterization of Groundwater Quality for Drinking and Agricultural Purposes: A Case Study in Rafsanjan Plain, Iran. Water Qual. Expo. Health 2015, 7, 531-544.

Iqbal,H.H.;Shahid, N.;Qadir,A.;Ahmad,S.R.;Sarwar, S.; Ashraf, M.R.; Arshad, H.M.; Masood, N.Hydrological and Ichthyological Impact Assessment of Rasul Barrage, River Jhelum, Pakistan. Pol. J. Environ.Stud. 2017, 26.

Jang, C.-S.; Chen, C.-F.; Liang, C.-P .; Chen, J.-S. Combining groundwater quality analysis and a numerical flow simulation for spatially establishing utilization strategies for groundwater and surface water in the Pingtung Plain.

J. Hydrol. 2016, 533, 541-556.

Jang, C.-S.; Chen, J.-S. Probabilistic assessment of groundwater mixing with surface water for agricultural 
Krishnakumar, P .; Lakshumanan, C.; Kishore, V .P .; Sundararajan, M.; Santhiya, G.; Chidambaram, S. governing factors influencing the spatial variability of shallow groundwater chemistry in a tropical sedimentary 
Li P;He S;He X;Tian,R.Seasonal hydrochemical characterization and groundwater quality delineation based on matter element extension analysis in a paper wastewater irrigation area,northwest China.Expo.Health 2018a,10,241-258.

Li, P.; Qian, H.; Wu, J.; Zhang, Y .; Zhang, H. Major ion chemistry of shallow groundwater in the Dongsheng Coalfield, Ordos Basin, China. Mine Water Environ. 2013a, 32, 195-206.

Li, P .; Qian, H.; Zhou, W. Finding harmony between the environment and humanity: An introduction to the thematic issue of the Silk Road. Environ. Earth Sci. 2017, 76, 105.

Li P Y,Wu J H,Qian H. Assessment of groundwater quality for irrigation purposes and identification of hydrogeochemical evolution mechanisms in Pengyang County, China[J]. Environmental Earth Sciences,2013b,69(7).

Li, P .; Wu, J.; Qian, H. Hydrochemical appraisal of groundwater quality for drinking and irrigation purposes and the major influencing factors: A case study in and around Hua County, China. Arab. J. Geosci. 2016a,9, 15.

Li, P; Wu J; Qian H; Zhang Y;Yang N;Jing L;Yu P.Hydrogeochemical characterization of groundwater in and around a wastewater irrigated forest in the southeastern edge of the Tengger Desert, Northwest China.Expo. Health 2016b, 8, 331-348.

Li, P .; Wu, J.; Tian, R.; He, S.; He, X.; Xue, C.; Zhang, K. Geochemistry , Hydraulic Connectivity and Quality Appraisal of Multilayered Groundwater in the Hongdunzi Coal Mine, Northwest China. Mine Water Environ.2018b, 37, 222-237.

Li, P .; Zhang, Y .; Yang, N.; Jing, L.; Yu, P . Major ion chemistry and quality assessment of groundwater in and around a mountainous tourist town of China. Expo. Health 2016c, 8, 239-252.

Liang C P;Jang C S;Chen C F, Chen J S. Zonal management of multi-purposes groundwater utilization based on water quality and impact on the aquifer. Environ. Monit. Assess.2016,188,431. 

characteristics of soil salinity in arid irrigated agro-ecosystems using integrated approaches[J].

Liu X,Xiang W,Si B C.Hydrochemical and isotope characteristics in the shallow groundwater of the Fenhe River basin and indicative siginificance[J]. Environmental Science, 2021, 42(4),doi: 10.13227/j.hjkx.202008315.(In Chinese)

Ma J H,Yang S Q,Shi H B, Ding X H, Han W G. Irrigation System of Maize in Hetao Irrigation District Based on Soil Water and Salt Threshold[J].Transactions of the CSAE,2014,30(11):83-91.(In Chinese)

Marghade, D.; Malpe, D.; Zade, A. Major ion chemistry of shallow groundwater of a fast growing city of Central India. Environ. Monit. Assess. 2012, 184, 2405-2418.

Ministry of Health of PRC, Standardization Administration of PRC. Standard Examination Methods for Drinking Water; GB/T5750-2006; Standards Press of China: Beijing, China, 2006. (In Chinese)

Nishanthiny SC, Thushyanthy M, Barathithasan T, Saravanan S(2010) Irrigation water quality based on hydro chemical analysis,Jaffna, Sri Lanka. Am-Eur J Agric Environ Sci 7:100-102.

49.Prasanth, S.V .S.; Magesh, N.S.; Jitheshlal, K.V .; Chandrasekar, N.; Gangadhar, K. Evaluation of groundwater quality and its suitability for drinking and agricultural usein the coastal stretch of Alappuzha District, Kerala,India. Appl. Water Sci. 2012, 2, 165-175.

Ravikumar, P .; Somashekar, R.; Angami, M. Hydrochemistry and evaluation of groundwater suitability for irrigation and drinking purposes in the Markandeya River basin, Belgaum District, Karnataka State, India. Environ. Monit. Assess. 2011, 173, 459-487.

Ren D Y ,Wei B Y ,Xu Xu,Engel B,Li G Y ,Huang Q Z ,Xiong Y W ,Huang G H. Analyzing spatiotemporal 
Saxena, V .; Ahmed, S. Dissolution of fluoride in groundwater: A water-rock interaction study. Environ. Geol.2001, 40, 1084-1087.

Shi H B,Guo J W,Zhou H, Wang G S, Fu X J,Li Z Z. Effects of irrigation amount and groundwater regulation on soil water andsalt distribution in arid areas[J].Transactions of the Chinese Society for Agricultural Machinery,2020,51(04):268-278.(In Chinese)

Singh, A.K.; Mondal, G.; Tewary , B.; Sinha, A. Major Ion Chemistry, Solute Acquisition Processes and Quality Assessment of Mine Water in Damodar Valley Coalfields, India. In Proceedings of the International Mine Water Conference, Pretoria, South Africa, 19-23 October 2009.

Taheri, M.; Gharaie, M.H.M.; Mehrzad, J.; Afshari, R.; Datta, S. Hydrogeochemical and isotopic evaluation of arsenic contaminated waters in an argillic alteration zone. J. Geochem. Explor. 2017, 175, 1-10.

Tahmasebi, P .; Mahmudy-Gharaie, M.H.; Ghassemzadeh, F.; Karouyeh, A.K. Assessment of groundwater suitability for irrigation in a gold mine surrounding area, NE Iran. Environ. Earth Sci. 2018, 77, 766.

Tang J P, Zhang Q,Hu Y, Zhang Y, Nie B W. Groudwater chemical characteristics and controlling factors nalysis in alluvial fan of Jianjiang River [J]. Environmental Science, 2019, 40(7): 3089-3098.(In Chinese)

Wang G S,Shi H B,Li X Y, Zheng Q, Guo J Q, Wang W G. Water and salt transport law and equilibrium analysis among cultivated land, wasteland and Haizi in Hetao irrigation area[J].Journal of Hydraulic Engineering,2019,50(12):1518-1528.(In Chinese)

Wang J B,Zhu L P,Ju J T, Wang Y. Water chemistry of eastern Nam lake area and inflowing rivers in Tibet[J].Scientia Geographica Sinica, 2009, 29(2): 288-293.(In Chinese)

Wen Y,Qiu J H,Cheng S, Xu C C, Gao X J. Hydrochemical Evolution Mechanisms of Shallow Groundwater and Its Quality Assessment in the Estuarine Coastal Zone: A Case Study of Qidong, China[J]. International Journal of Environmental Research and Public Health,2020,17(10). 
Wilcox, L. Classification and Use of Irrigation Waters; Agriculture Circular: Washington, DC, USA, 1955; p. 19.

World Health Organization (WHO). Guidelines for Drinking Water Quality, 4th ed.; WHO: Geneva, Switzerland,2011.

World Health Organization (WHO). Guidelines for Drinking Water Quality; World Health Organization:Geneva, Switzerland, 2004.

Wu, J.; Li, P .; Qian, H.; Duan, Z.; Zhang, X. Using correlation and multivariate statistical analysis to identify hydrogeochemical processes affecting the major ion chemistry of waters: A case study in Laoheba phosphorite mine in Sichuan, China. Arab. J. Geosci. 2014, 7, 3973-3982.

Wu, J.; Li, P .; Qian, H. Hydrochemical characterization of drinking groundwater with special reference to fluoride in an arid area of China and the control of aquifer leakage on its concentrations. Environ. Earth Sci.2015, 73, 8575-8588.

Xu P P, Feng W W, Qian H, Zhang Q Y. Hydrogeochemical Characterization and Irrigation Quality Assessment of Shallow Groundwater in the Central-Western Guanzhong Basin, China[J]. International Journal of Environmental Research and Public Health,2019,16(9).

Yuan H Y,Yang S Q,Ding X H, Wang Bo, Yang X M. Evolution characteristics of nutrients and chemical compositions of groundwater before and after autumn irrigation - Taking Wulate Irrigation Area as an Example[J].Environmental Chemistry,2019,38(10):2336-2347.(In Chinese)

Zeng H B, Su C L, Xie X J, Pan H J, Ji Q N, Tao Y Z. Mechanism of Salinization of Shallow Groundwater in $\begin{array}{llll}\text { Western } & \text { Hetao } & \text { Irrigation } & \text { Earth }\end{array}$ Science :1-17[2021-01-08].http://kns.cnki.net/kcms/detail/42.1874.P.20200902.0756.002.html.(In Chinese)

Zhang T, He J, Li J J, Cao Y T, Gong L, Liu J W, Bian C, Cai Y M. Major ionic features and possible controls in the groundwater in the Hamatong River Basin[J]. Environmental Science, 2018, 39(11): 4981-4989.(In Chinese) 
Fig. 1 Location map of the study area and sampling sites

Fig. 2 Box plots of the major ions in the Shenwu and Wulate Irrigation Areas

Fig. 3 Piper diagram of the chemical compositions of shallow groundwater

Fig. 4 Gibbs Diagram of the study area

Fig. 5 Relationships among the $\mathrm{Ca}^{2+} / \mathrm{Na}^{+}, \mathrm{HCO}_{3}{ }^{-} / \mathrm{Na}^{+}$, and $\mathrm{Mg}^{2+} / \mathrm{Na}^{+}$of the study area's groundwater resources

Fig. 6 Ion correlation diagram of the shallow groundwater resources in the Shenwu and Wulate Areas

Fig. 7 Changes in the diversion and drainage processes of the Shenwu and Wulate Areas

Fig. 8 Spatial distribution map of the groundwater table depths in the study area

Fig. 9 Wilcox diagram for the irrigation water quality assessments in the Shenwu and Wulate Areas

Fig. 10 USSL diagram for the irrigation water quality assessments in the Shenwu and Wulate Areas

Fig. 11 Doneen Diagram for assessing the quality of the irrigation water in the Shenwu and Wulate Areas

Table 1. Physicochemical groundwater characteristics and statistical features

Table 2. Classification of the quality of the groundwater for irrigation processes based on the RSC (Ghalib et al.2017) and RSBC (Gupta et al.1987) 
813 Table 3. Classification of the quality of the groundwater for irrigation processes based on the

Table 1

\begin{tabular}{|c|c|c|c|c|c|c|c|c|c|c|}
\hline \multirow{3}{*}{ Project } & \multicolumn{5}{|c|}{ SWIA } & \multicolumn{5}{|c|}{ WLTIA } \\
\hline & Minimum & Maximum & Mean & Standard & Coefficient & Minimum & Maximum & Mean & Standard & Coefficient \\
\hline & & & & deviation & of variation & & & & deviation & of variation \\
\hline $\mathrm{pH}$ & 7.21 & 8.32 & 7.72 & 0.26 & 0.03 & 7.27 & 8.81 & 7.85 & 0.31 & 0.04 \\
\hline TDS/ $\left(\mathrm{g} \cdot \mathrm{L}^{-1}\right)$ & 0.26 & 13.06 & 1.84 & 2.41 & 1.31 & 0.33 & 56.4 & 3.6 & 8.53 & 2.37 \\
\hline $\mathrm{Cl}^{-} /\left(\mathrm{g} \cdot \mathrm{L}^{-1}\right)$ & 0.09 & 6.65 & 0.54 & 1.06 & 1.96 & 0.07 & 25.88 & 1.36 & 3.95 & 2.90 \\
\hline $\mathrm{SO}_{4}{ }^{2-} /\left(\mathrm{g} \cdot \mathrm{L}^{-1}\right)$ & 0.07 & 2.40 & 0.47 & 0.53 & 1.13 & 0.07 & 15.13 & 0.69 & 2.27 & 3.29 \\
\hline $\mathrm{HCO}_{3}{ }^{-} /\left(\mathrm{g} \cdot \mathrm{L}^{-1}\right)$ & 0.11 & 1.74 & 0.43 & 0.27 & 0.61 & 0.14 & 1.25 & 0.58 & 0.23 & 0.40 \\
\hline $\mathrm{Ca}^{2+} /\left(\mathrm{g} \cdot \mathrm{L}^{-1}\right)$ & 0.02 & 0.36 & 0.09 & 0.06 & 0.66 & 0.01 & 0.80 & 0.14 & 0.14 & 0.09 \\
\hline $\mathrm{Mg}^{2+} /\left(\mathrm{g} \cdot \mathrm{L}^{-1}\right)$ & 0.02 & 0.61 & 0.09 & 0.10 & 1.13 & 0.01 & 1.28 & 0.14 & 0.19 & 1.36 \\
\hline $\mathrm{Na}^{+} /\left(\mathrm{g} \cdot \mathrm{L}^{-1}\right)$ & 0.07 & 4.38 & 0.5 & 0.79 & 1.57 & 0.05 & 22.93 & 1.09 & 3.47 & 3.18 \\
\hline
\end{tabular}

Table 2

\begin{tabular}{|c|c|c|c|c|}
\hline \multirow[t]{3}{*}{ Evaluating indicator } & \multirow[t]{2}{*}{ Range } & \multirow[t]{2}{*}{ Remark on quality } & \multicolumn{2}{|c|}{ Sample number and percentage } \\
\hline & & & SWIA & WLTIA \\
\hline & $<1.25$ & Good & $38(90.48 \%)$ & $39(90.70 \%)$ \\
\hline RSC & $1.25-2.5$ & Doubtful & $2(4.76 \%)$ & $2(4.65 \%)$ \\
\hline \multirow[t]{2}{*}{$\left(\mathrm{meq} \cdot \mathrm{L}^{-1}\right)$} & $>2.5$ & Unsuitable & $0(0 \%)$ & $1(2.33 \%)$ \\
\hline & $>5$ & Harmful to plant & $2(4.76 \%)$ & $1(2.33 \%)$ \\
\hline
\end{tabular}




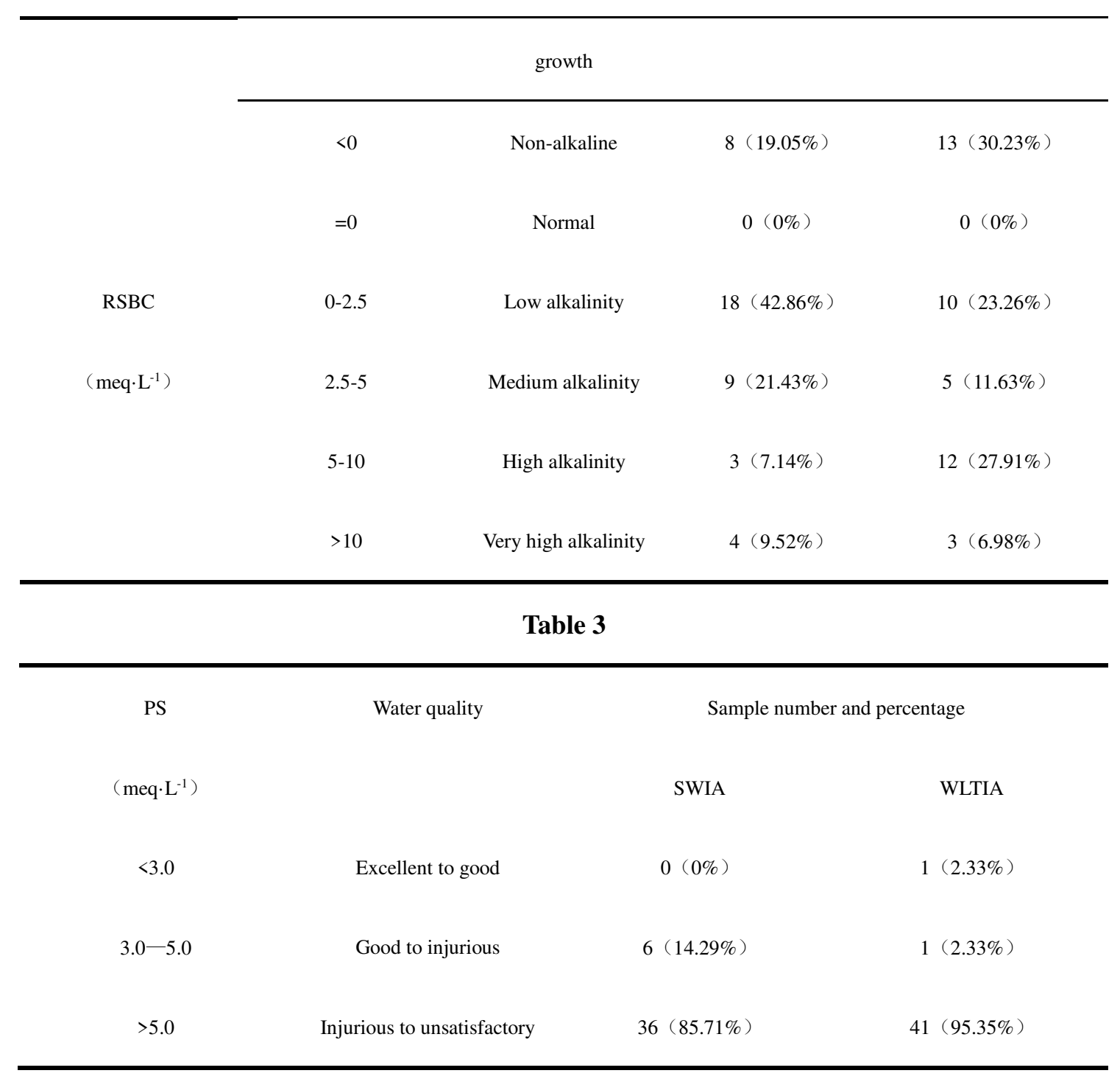

818

819 


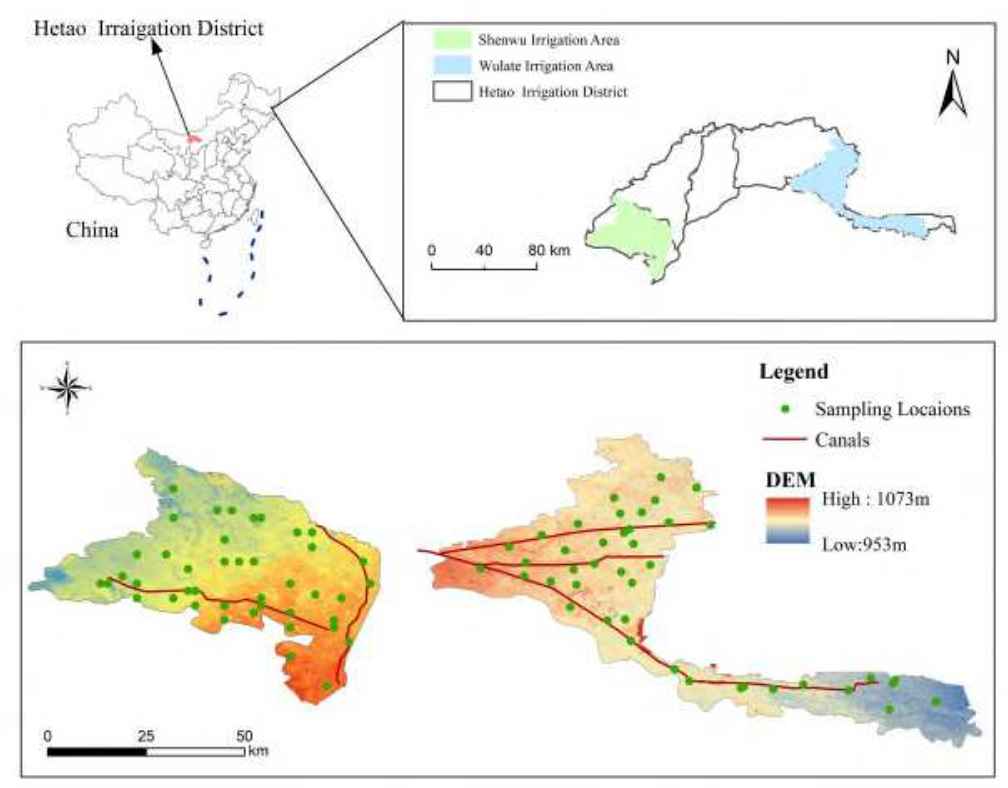

Fig. 1

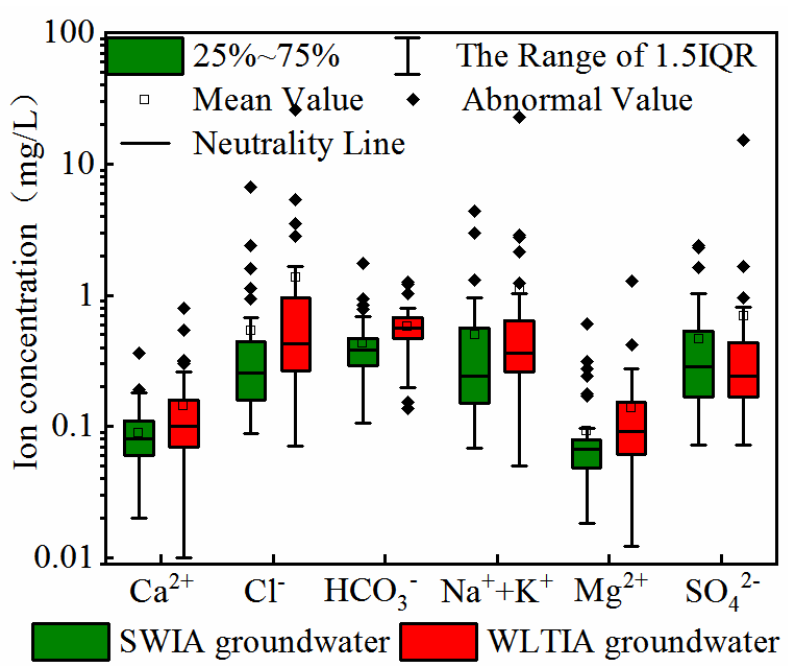

823

Fig. 2 


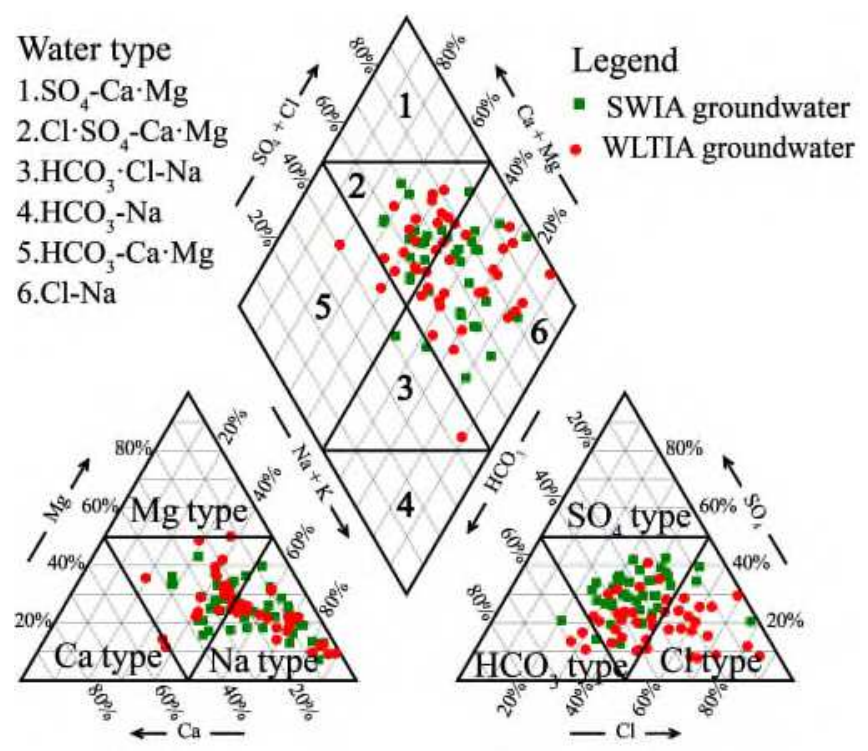

Fig. 3
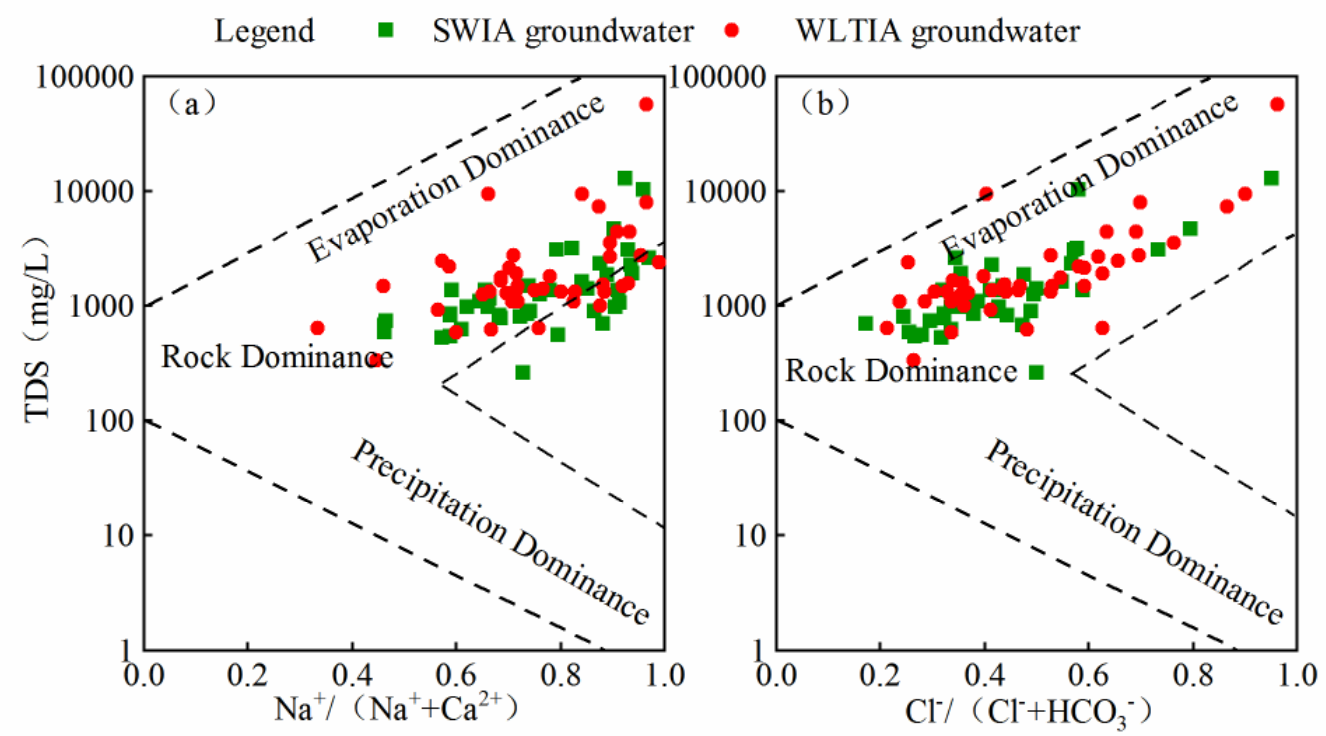

Fig. 4
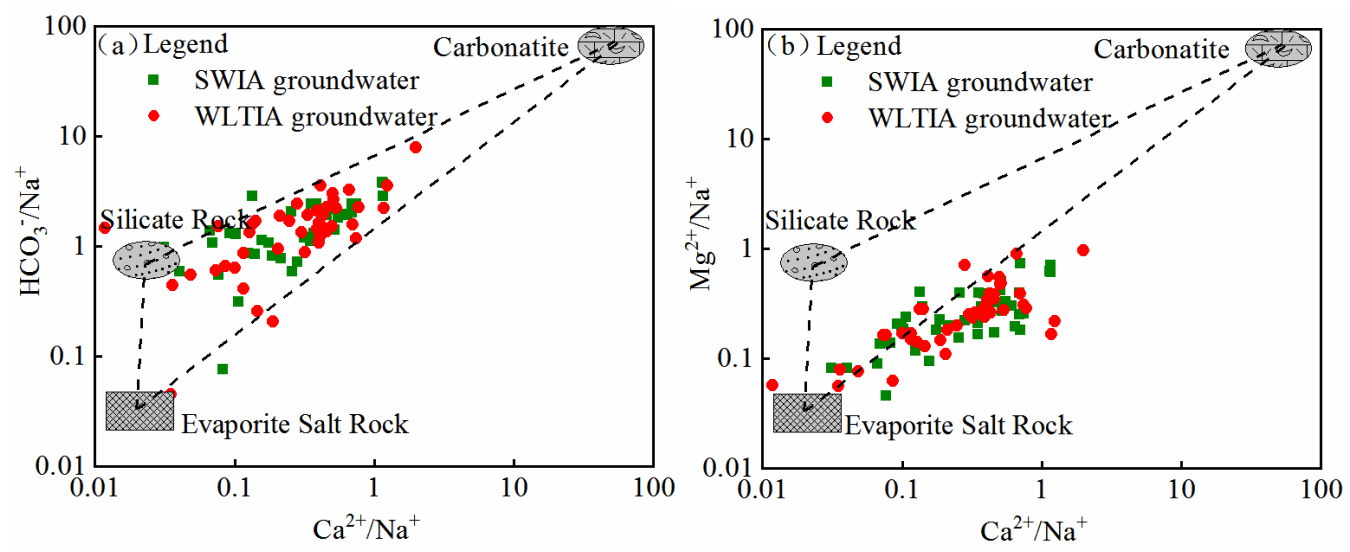
Fig. 5
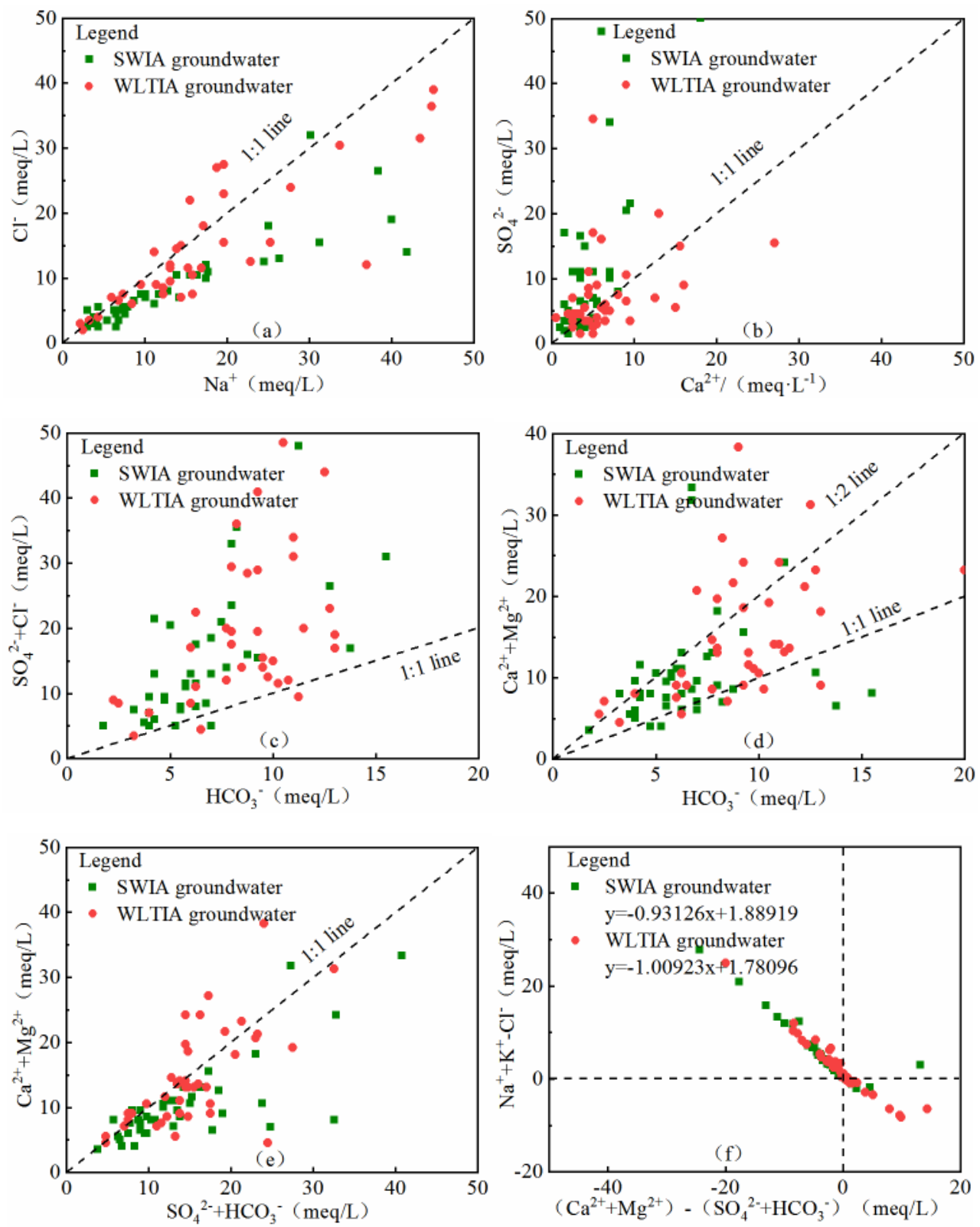

Fig. 6 


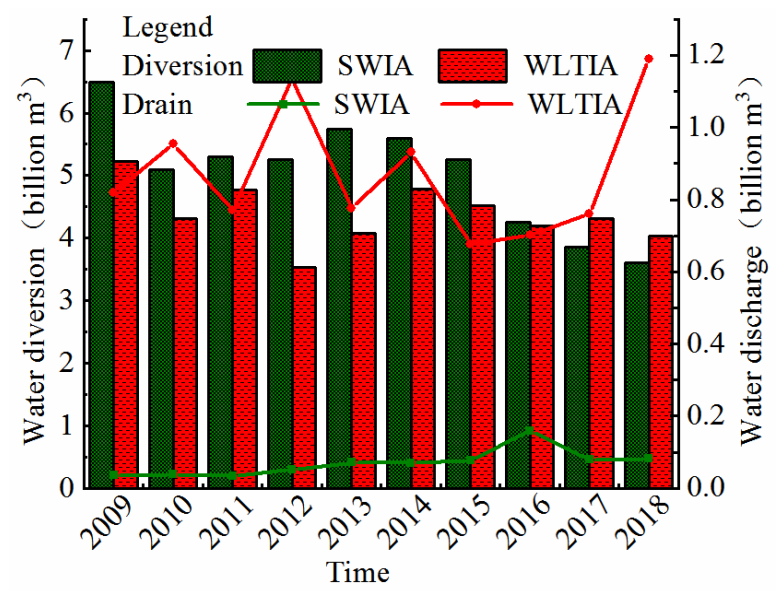

Fig. 7
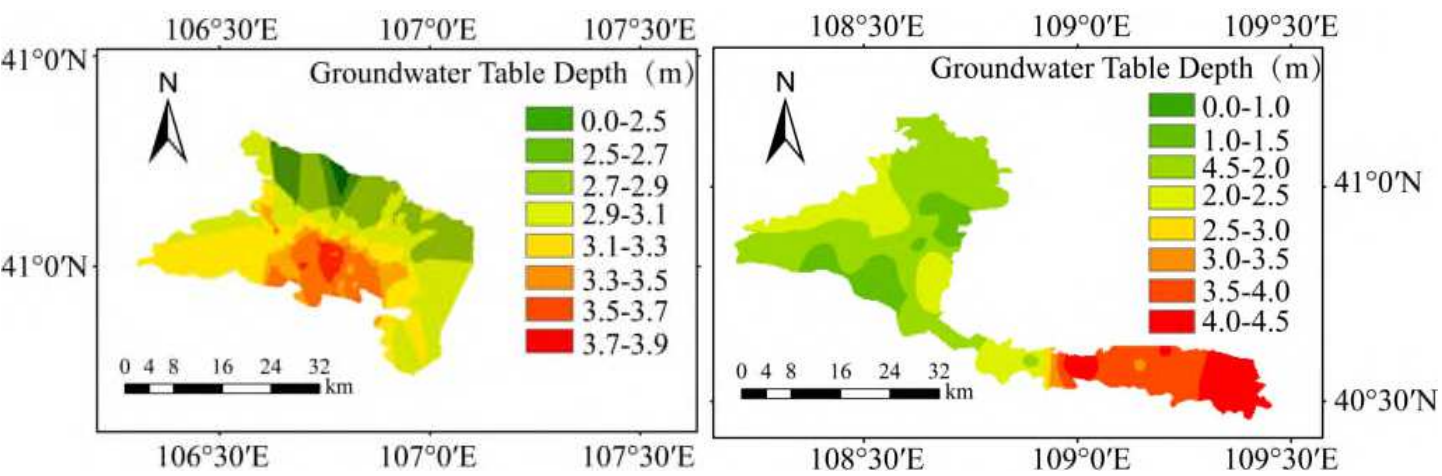

Fig. 8

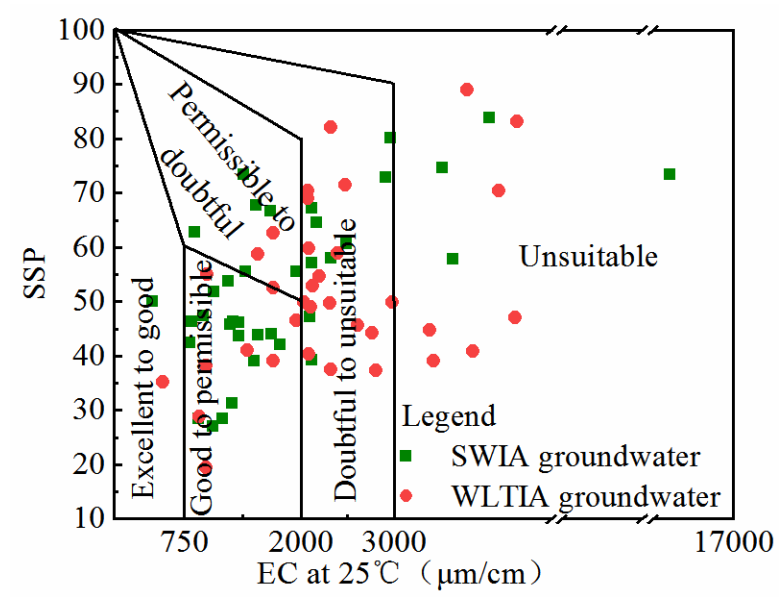

Fig. 9 


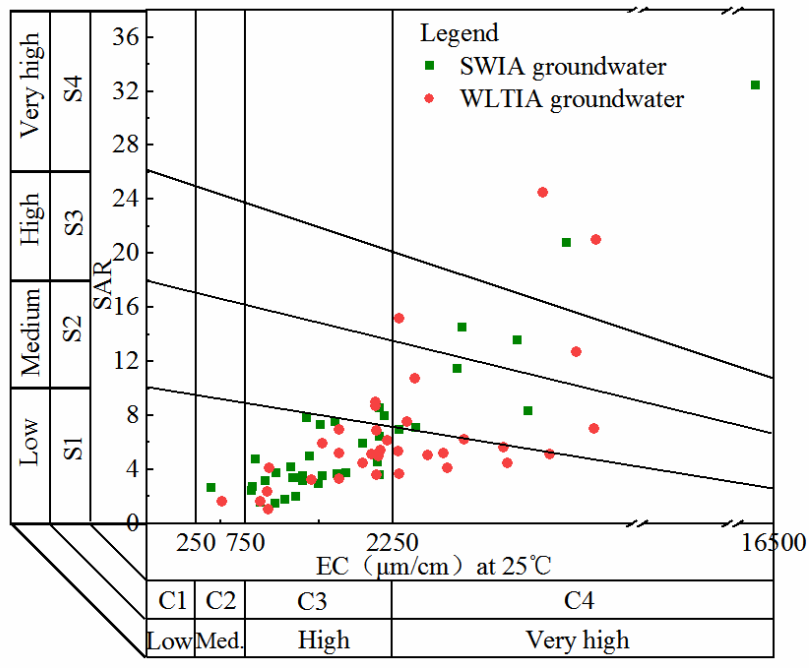

Fig. 10

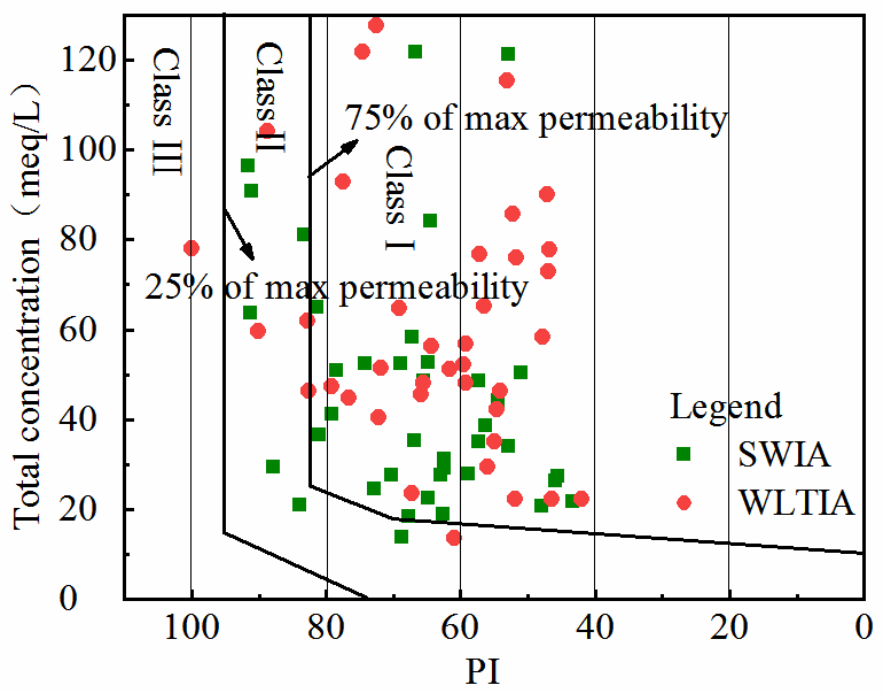

